\title{
Photographic image in the commercial messaging as an immanent element of the city landscape
}

\author{
Agnieszka Chęć-Małyszek \\ Department of Architecture, Urban and Spatial Planning, Faculty of Civil Engineering \\ and Architecture,University of Lublin,e-mail: a.chec-malyszek@pollub.pl
}

\begin{abstract}
Cities, as the centres for the people's existence, have become an ideal place for interweaving the commercial into their landscape. Advertisement has become a part of our lives and one cannot imagine today's metropolis without billboards. In the culture of the city, the commercial has started to be an integral part of the city landscape which used to play an important role in social and cultural life of citizens creating by that a specific culture. Photography,invariably linked with advertisement, might be manifested by all sorts of creative actions, forming one of the most important means of creative expression. While watching commercials, we tend to notice not only what marketing profesionals are trying to sell but also how they are going to introduce the product. Advertisement is associated with a public space, influences its development and arrangement.
\end{abstract}

Keywords: picture, photography, advertising, advertising photography, city landscape.

\section{Introduction}

Recent years have shown that the ubiquitous display of advertisements in public spaces gathers widespread discussion which has led to the introduction of several limitations in the matter. Raised public awareness of the growing problem has caught the attention of local authorities and, in consequence, was effected with some changes to the regulations from 24th April 2015 and strengthening the tools of the city landscape preservation [1].

Omnipresent visual advertising, being intrinsically linked to the growth of civilizational development, apart from channelling crucial pieces of information, they also tend to irritate and disgust citizens. The civilizational growth and economical well-being have resulted in the surge of consummerist practices which directly correlated with the need to possess more and more products. Commercial images, as the outcome of clever marketing strategies, usually have their underlying, subconscious influence on the receivers making them want more and more goods. One can enumerate several types of commercial display one of which is the most frequently used, namely, photographic images such as, for example, billboards, city lights, city scrolls, banners, LCD screens, nets, advertising pylons, posters or roll-ups. Their fundamental characteristic is the forceful, aggressive presence in public spaces available to the unlimited number of viewers.

The phenomenon has sparked wide discussion reflected in a number of publications on the matter which have been the aftermath of greater popularity of that means of information exchange. The problem of the presence of commercial imagery in public space was frequently tackled by K. Iveson [2] or A. M. Cronin [3]. Although numerous opponents of that kind of images claim that they seem chaotic, distort the aesthetical layout of a city, cities and streets are brimmed with advertising media. 
The problem of outdoor advertising in public spaces was analysed in different publications where particular emphasis was placed on their negative influence on social environment [4]. However, little reference was set to the visual, photographic images which inluence the shape of public spaces and citizens' comfort. T. Wilson and B. D. Till [5] applied another perspective on the issue, namely marketing efficacy, whereas T. Nowicki [6] conducted some research on the influence of outdoor advertising media on a city iconosphere. J. Gehl advocates public spaces as the key centres of any citizen -friendly cities [7].

The aim of the paper is to show in what way a photographic advertising shapes and alters public spaces at the same time being their immanent element.

\section{Outdoor advertising media of the city}

The history of an outdoor advertising has been strongly linked with the development of cities, dating back to the antiquity. For centuries, a primary aim of advertising was convincing the largest number of people to purchase, buy certain types of goods and services. Since the twentieth century it has been regarded as artistic form of expression and an element of mass culture. By using various media sources - the press, radio, television, film or poster, it has been an integral part of human life.

In Ancient Greece, the duty to promote and encourage people to buy products was bestowed on the so-called street announcer who used to roam over the city and announced some products for sale [8]. Similar mode of advertising was applied in the Middle Ages era when, on the city markets, street marketers - vendors, tradesmen shouted out the names and prices of their products creating, by that means, a verbal advertising channel [9]. The invention of printing and font in 1450 by Johannes Gutenberg was a major breakthrough in the development of advertising as people could promote their goods and services in newspapers where they included visual representations of their products [8].

The nineteenth century brought the emergence of the poster and printed press releases as two main, widely popular sources of advertising. The poster technique was introduced and developed by Jules Cheret - the author of over a thousand posters [10].

The twentieth century was the key period when the advertising flourished. The radio and cinema revolutionized the economic market by promoting the propaganda advertising [10]. The city played an important role in shaping the means of advertising at that time and functioned as a powerful platform for human expression.

Advertising techniques base on psychological knowledge of human types of behaviour being exposed to the promotion of products [11] and resort to the receiver's convincibility.

Early on, the advertisement was presented in various forms. Marian Golka, in his book entitled, Świat reklamy”, provides a concise definition of advertising:,,advertising might be understood as any paid form of impersonal presentation and advocacy of purchasing goods with the usage of particular means, within some defined framework of legal rules, appropriate conditions, together with a provision of information on the products in question, their positive characteristics and possibilities of purchase."[12]. A much simpler definition could be found in the work of Jack Kall who regarded advertising as, an impersonal (without the vendor and money factors) form of product praise" [13].

The origins (etymology) of a word,,reklama" (eng. commercial, advertisement) refers to the latin verb reclamo which means, scream, shout to someone, express loud objection, reverberate, echo". However, closer connotation to a contemporary meaning of the word would be the latin ,divulgo”- ,,announce, distribute” and „propago”- ,spread, propagate” [8]. 
Regardless of the definition applied, advertising is always a form of communication which includes information provider - addresser, addressee, some data input - message as well as the medium transmitting the message. The most fundamental goal of a commercial is repleting its receiver with adequate imaging and product branding by means of multiplication of content and displaying the values of services [11].

According to researchers, public space serves as a special, key platform for people's interaction, sharing opinions and services [7]. It forms a necessary core for a city jigsaw puzzle, integrates, boosts citizens' activity [14]. Its ties with andvertising media sparks fervent opinion sharing, contradictory emotions - whether they integrate with the city landscape or, just the opposite, distort its harmony. Despite great degree of criticism, it is still one of the most essential elements of massmedia culture and promotion.

\section{Photographic images in advertising content}

There are many branches in photography where certain techniques of image making predominate and elevate to a degree of art. Among them, advertising photography is one of the best-known.

The term,,photography” originates from the Greek:,photos” - light,,,graphein” - to draw, write by means of light. Photography aims at capturing life, motion, impression,,,freezing a moment" which will never come back [15]. The invention of photography dates back to 7th January 1839 when the technique of daguerreotype was introduced by Joseph Nicephore Niepce. In 1855, James Clerk Maxwell laid the foundations for today's photography by studying colour vision [16].

The twientieth century was named the era of photography because all the social, political and economic life was docummented with the help of that particular media leading to the development of press photo.

The artist aligns photography with another forms of artistic expression such as graphics or painting whereas proffesional photographers would include photography into a category of craftsmanship where the task is to create an image - ,a photo”. Scientists, engineers or physicians would categorize photography as some visual aid in research or technical or medical report [17].

In fact, photography may serve different functions but its main aim is to preserve in paper any types of phenomena, impression or information by means of light. In other words, it functions as a note, recollection in the form of an image.

Photography is a part of mass culture; everyone uses it, therefore, loses objectivity in the image reception. The difference between a proffesional photographer, an artist, a craftsman or an amateur becomes blurred. A sharp division into amateur, artistic or commercial photography is being replaced with their synergetic, interfacing nature.

Among various, well-known forms of adverisind, there is, photography, the one which deserves special attention for it operates only by means of vision to subconsciously influence its addressee. Photography may present a product in a direct or hidden manner, basing on immediate, quick associations.

Outdoor advertising is governed by its own inherent rules, is extended in time, resorts to photography, drawing and graphics. The first and foremost task of the advertising photography is the conveyance of a message by means of one strong image which is to last in mind of its addressee.

Advertising photography aspires to the form of art, becomes a tool of marketing proffesionals who use it to strengthen the message and deliver essential content of a product. 
The images function within their own unique reality, not inferequently, far from the truth. Today's world of advertising stands for unnatural, repeatedly perfected photographic image diverged from reallity.

\section{The role of a photographic image in advertising}

A photographic image plays one of the most important role in various advertising content. Its postion is sometimes even more salient than the heading or the added text. This is a strong, to-the-point photography which immediately attracts attention and encourages to get deeper into the content presented. It reflects reality, offers authenticity and presents a product in one-to-one correlation with its real-life object, being far more accurate than a drawing or painting.

Photography becomes a medium for vital pieces of information from a social and cultural life. The best commercials are those devoid of any textual message, operating only with intense images. The author of a commercial has got real manipultive power in choosing the right image which subconsciously influences the addresses's opinions and tastes. Photographic image comes out of an interplay between shadow and light within the picture. Compositional balance arrives out of correct placement of light and shadow. The shadows emphasize main characteristics of an object and give it an artistic vibe while the light around the object adds to its volume [18].

Technical aspects of photography such as lighting, adequate perspective or an appropriate medium strengthen the forceful image intake.

The image perception arises out of emotional response, sharpness of sight accompanied by knowledge and experience. The image might move the addressee without influencing their degree of visual competence. It could be achieved by mechanical, automatic seeing, perceiving to which people accommodate in reference to their needs. The essence of perception is the fact that the viewer not always applies technical means and denotes reality as an objective image [19].

Adequate attribution of a medium, by means of which the picture is distributed or multiplied, impacts its finite reception. The photographic image attracts greater trust of the viewer even though the transmitted picture has been modified. Nonetheless, excessive picture distortion could be easily noticed by the viewer which may result in their reluctance to accept the advertising image [19].

Oliviero Toscani claimed that,, a photography in itself is a product and photographic images should be treated as the epitomes of beauty". He assumed that the increase in aesthetics of an advertising photography might have direct correlation with the surge in sales. Additionally, the picture is deemed beautiful when it,can sell' more items of a product or increase interest in the services provided [20].

One of the essential functions of advertising photography is its degree of persuasion. A skillful advertiser uses advertising photography to manoeuvre the addressee into the reaction which was presupposed by the advertiser. Graphic imagery as used in photography allows for certain linguistic motives. Correct graphic representation deliberately mythologizes reality, refering to the context of clichéd myths reverberating in culture and public mentality [21].

Digital technology predominates in delivering commercial images. The boundary of designing tools becomes blurred when some elements of drawing, photography and graphics are incorporated. It gives the ability to combine mass culture with hand-made, artistic craftsmanship which gets represented by numbers of illustrations, drawings and photographs. 


\section{Psychological aspects of a photographic image used in advertising}

From its beginings, photography enabled the viewer to enter another dimension of visual reality. It possessed forceful advertising quality and photographers used it as a representation of their craft. Owing to its powerful influence, they could possess customers to create family and occasional photos which used to be the main subjects of a picture taking. In spite of a total change in the technology of photography, the early, universal canons have remained until today. A photographic image enables its recipients to study visual values and try to decipher information. Quite incessantly is the image altered due to optical distortion, however, they still manage to believe in its realism.

The reception of an image is an individual, unique perception of an object as more or less good representation of reality sieved by the experiences of the viewer [19].

From a psychological standpoint, the human being was placed at the centre; nothing has changed in that matter. Visual image imprints in memory much more often than the most picturesque audible data transmission. While analysing a photographic image, the viewer refers to their own experience, therefore, each addressee may interprete the same picture differently. Pictures used in advertising photography attempt at convincing the customer that they need and want the product. Advertising marketers are so skilled in product promotion strategies that they easily make it more attractive and buyer - friendly. The crucial goal of photography is to evoke or sustain psychological tension. It should create needs, boost pleasure and provoke the indispensable urge to possess the advertised product or service.

In reality, the true essence of visual advertising content is deeply rooted in psychology. Advertising photography aims at winning the customer's trust and changing their way of thinking and perceiving the world which involves selection, organisation and interpretation of data. It is individually determined and depends on a human personality and a type of stymulus. Filtering the information relies on applying all the senses in order to trace and then measure the intensity of the information which is received by auditory, olfactory, visual, tactile and taste organs. Some advertising images are characterised by low stimuli rate, therefore, they come unnoticed. Another important element of human perception is the presence of psychological filters which group data according to the people's individual interests and feelings. The presence of both filters shapes a person as a recipient of signals which influence their conscience. However, not all the pieces of information are filtered in through ones conscience since the process of perception is characterised by selectivity [11].

Additionally, perception is also governed by some degree of emotionality and the recurring memories, symbols and patterns from the past through which the images are sieved. Our memory keeps the information which has its backup in previous observations.

\section{Advertising images as an itegral element of the city landscape}

Within the last few years, the problem of chaotic advertising viewed in the city landscape has ignited fervent political discussion. Therefore, it is justifiably necessary to introduce serious changes to the law regulating the organisation of public city spaces. In 2013, the government altered the presidential draft laws on the preservation of landscape namely, regulations concerning advertising carriers placed in public spaces. The presidential act coined the definition of landscape as the result of a creative work of architects, at the same time, ordering local governments to instigate harsher control over the placement of advertising carriers in cities. 
An excellent background for the advertisement happens to be the immediate surrounding integrated with a building which mesmerizes, gives an illusion of some sort of street art. Cities, with their great number of citizens - viewers, have become ideal places to weave advertising images into their fabric. Grey city walls are, beautified' by colourful banners, billboards atrracting the attention of passers-by. That type of advertising possesses great potential, if used adequatelly, might serve the city well and be frequently developed by publicity experts who still weigh their choices verging on the limitations of law, morality and good taste.

Advertising is usually associated with large billboards, city lights, scroll, net, banners perceived as modern, non-standard media, some active, moving objects, the other in the form of a poster. It could be seen in the streets, public, frequently visited places, in public transportation system [22]. A key role of the advertising images is to deliver a message to walkers- by going different directions in the city in the easiest way possible.

Advertising relies primarily on a good, straight-to-the-point medium which could boost imagination. As professor Rafał Ohme states:, Regardless of what product is promoted, these are the images which provoke positive reactions in their viewers [...] The addressee of the message is not a rational, pragmatic, analysing persona but an emotionally, intuitively driven, wavering customer whose choices are done unwittingly, subconsciously and automatically." [23].

One of the most fundamental forces of an outdoor advertising is its location in an open space. Coded messages, patterns are subconsciously deciphered by their recipients wherever they encounter the information. Moreover, an open space allows for great degree of exposition [24].

David Bernstein writes:,,within time, some billboards turn into important focal, orientation points in the city landscape." [24]. He also claims that it is the aim of every publicity creator to have a piece of work so deeply ingrained in the city context. In that sense, an advertising image is not only a message conveyer but also an integral pervasive element of a public space, consequentially shaped by that medium.

A city public space forms an integral part of the city landscape, an area between buildings, devoted also to communication. It might sometimes stand for the city itself. Public space consists of buildings, streets, bus stops or city green areas. All these elements are constant, unchangeable and strictly connected to the architecture of the city. Advertising imagery in a city space functions as an add-on, limiting spatial emptiness around and positioning the space at some different degree of importance. Rapid development of cities has impacted the increase in the advertising images presented which have become a solid part of a city landscape. The advertisement does not shape the place but it forms one of the elements that belong to it. Appropriate positioning of the advertising message makes it far more communicative. Its permanent positioning in a given space and continuous interaction with other elements of the space makes the space unique [24].

A building whose architectural significance is little does not stand out in the city landscape but is characterised by its code and intrinsic message. In the times of consumerism, public space does not exist without an advertising image which creates a special atmosphere of a city landscape. Users of space usually associate some particular place with the advertisement present there and treat the image as a reference point in space. Society has accepted advertising as an element necessary in shaping a unique city space. However, the marketing media overflooding have had a negative impact on their recipients and turned into chaotic, intruding collection of random images.

Contemporary social communication processes are tightly linked with the presence of advertising media. Not only do they play a commercial function, but also become a part of 
social interaction. Therefore, positive examples of advertising images easily integrate into a city landscape and may decide on the city's distinctive character [25].

In everyday life, people are showered with plenty of audio and visual messages which might sometimes be tiring and discouriging. (Fig. 1, 2, 3) Reasonable selection of that data overflow can pose some real difficulty for the addressee. Not infrequently, is the message subconsciously delivered which causes chaos and irritation. In spite of that, the message recipient consciously tries to disregard the information provided. Most possibly, it is not only the excess of messages that creates a problem, but also the inappropiate form and localisation. (Fig. 4 and 5)
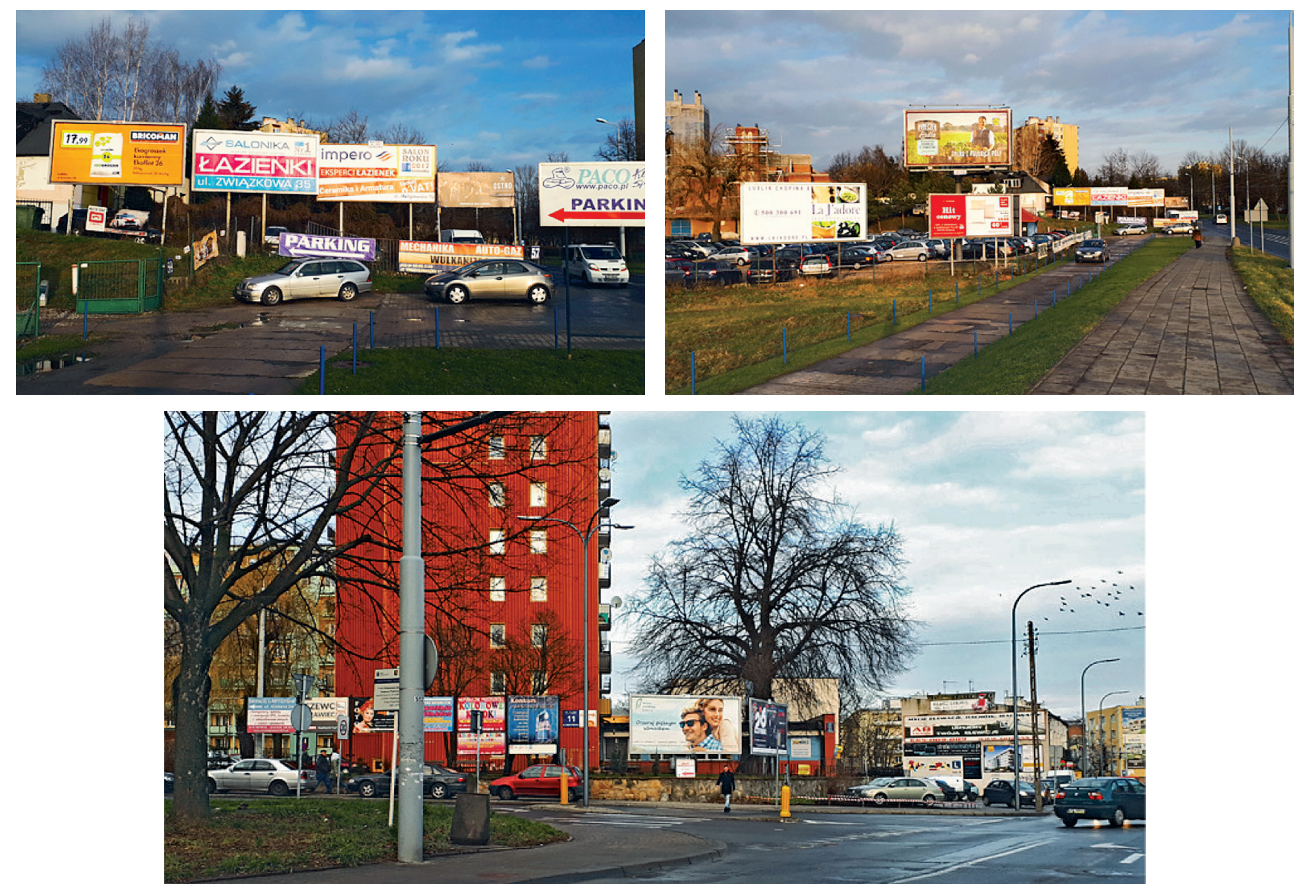

Fig. 1, 2, 3, A photography illustrating chaotic, disorganised arrangement of advertising in the Lublin city landscape, Nadbystrzycka St.; Author's photography, 2017 r.

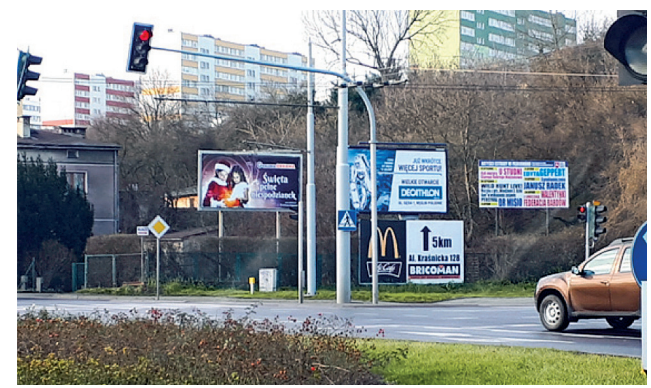

Fig. 4. The photography illustrating the chaotic city landscape, the crossroads of Nadbystrzycka and Jana Pawła. Author's photography, $2017 \mathrm{r}$.

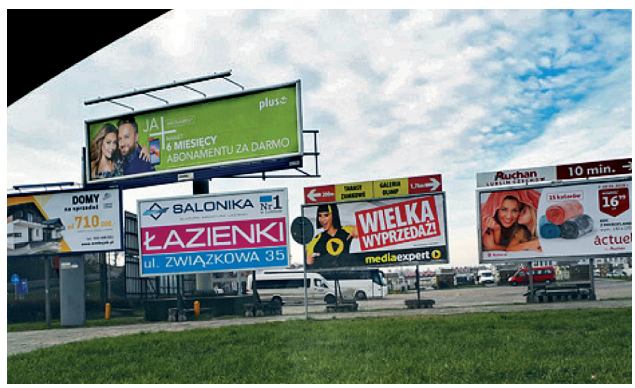

Fig. 5. The photography illustrating the excess of advertising located in Aleja Unii Lubelskiej in Lublin. Author's photography, $2017 \mathrm{r}$. 
In some cities, advertising has become an integral part of a city public space and is perceived as an emblem of the place. Such characteristic spaces of cities as, for example, Times Square in New York or Piccadilly Circus in London (Fig. 5, 6) are also recognised by their advertising elements exposed for so many years that they do not disrupt the overall reception of the place, quite the opposite, add some unique value to the space.

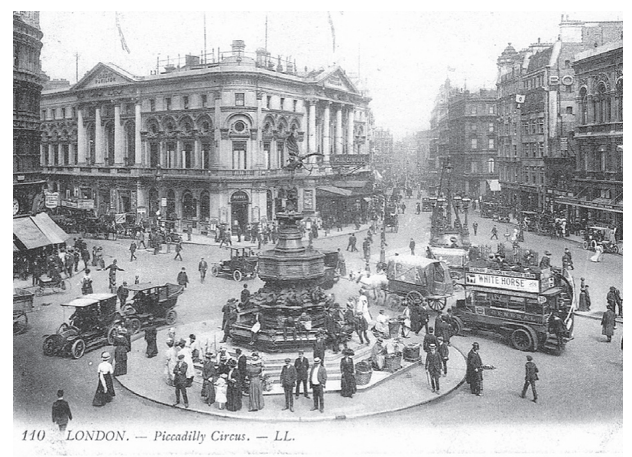

Fig. 6. Piccadilly Circus in London. A postcard view from 1981 sent by Anna Dyńska living in London.

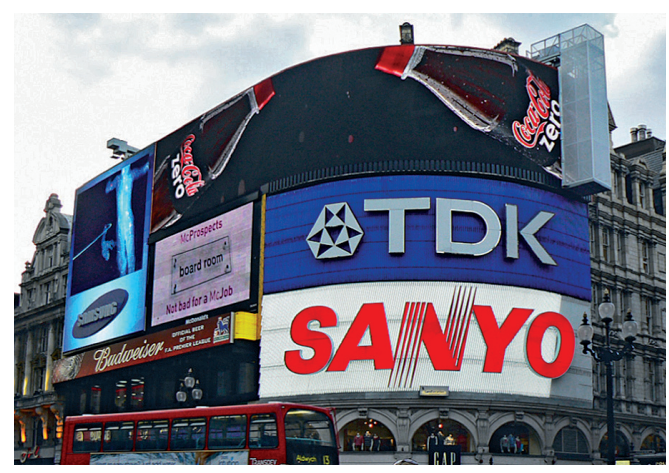

Fig. 7. Piccadilly Circus in London, 2003. Author's photography.

The process of integrating advertising into the city landscape was begun by the introduction of the first poster created in New York in 1835. From then on, it has started to be one of the most representative and characteristic elements of a metropolis and the most straightforward means of delivering a message to concumers. The opponents of advertising images claim that they disorganise the city landscape, whereas the proponents value their artistic, aesthetical features triggering the attractiveness of a city. Additionally, it is important to mention the visual aspect of advertising as it brings some colour to the city spaces, for example, by covering old, dilapidating buildings. Advertising has stopped to disturb consumers' everyday lives and even deserves to have a positive impact; it invariably happens to surprise the viewers, make them laugh or succeed in conveying an itelligent interaction with the existing surrounding. The image is no longer neutral to its context but aspires to deliver concise information centered around a human being.

Information transfer, in the form of advertising image contributes to, a picturesque view of the city /.../, positive at times, especially in some boring and mediocre city areas." [26].

Nowadays, the most developed form of message is an outdoor adverising which has become one of the most obvious elements of city public spaces but, at the same time, started to shape them by covering permanent parts of the city landscape. A problem whether to include advertising into a branch of art has remained unsolved.

Among different types of advertising, mural painting deserves special attention. (Fig. 8, $9,10)$. Historically, it dates back to the times of the Secong World War during which it served as one of very few ways of public communication. Mural, as a form of art and an example of wall painting [27], aims at promoting a product or illustrating an important, memorable social event with the use of artistic means of expression. 


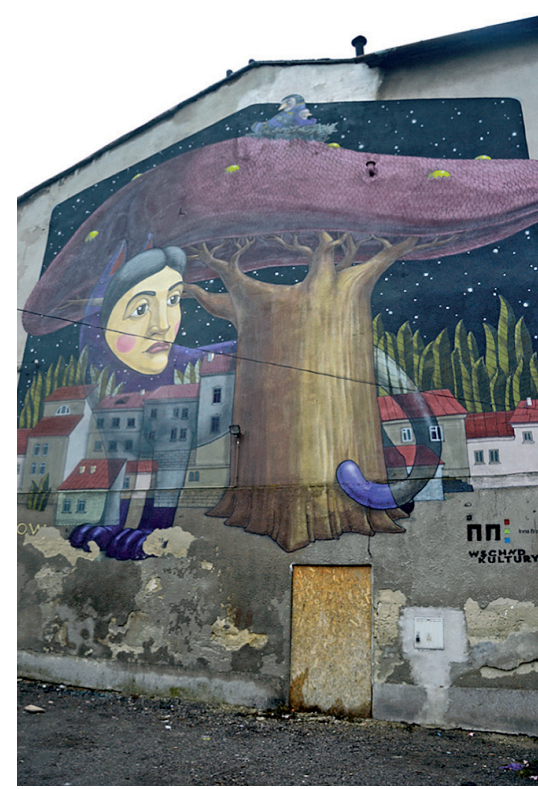

Fig. 8. Mural commemorating Festival Other Voices in Lublin located on the one of thewalls of an old building at Lubartowska St. in Lublin Author's photography, 2016 r.

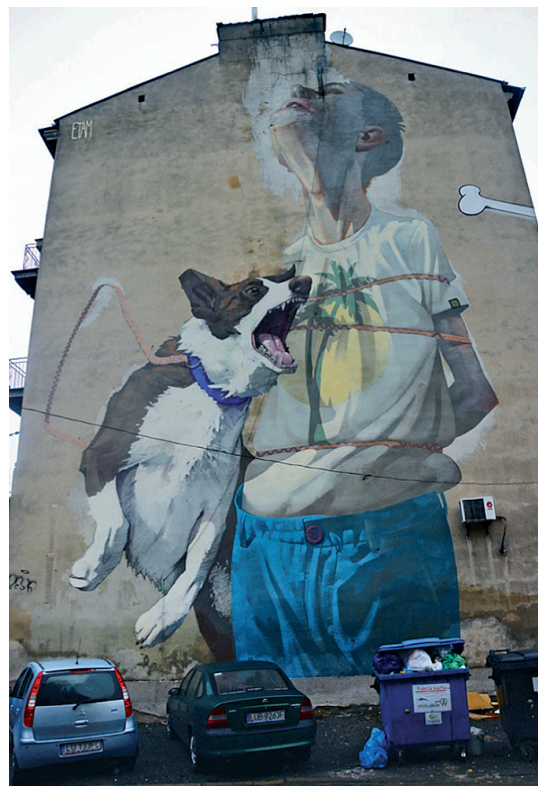

Fig. 9. Mural located on one of the walls of an old building at Lubartowska street in Lublin. Author's photography, $2016 \mathrm{r}$.

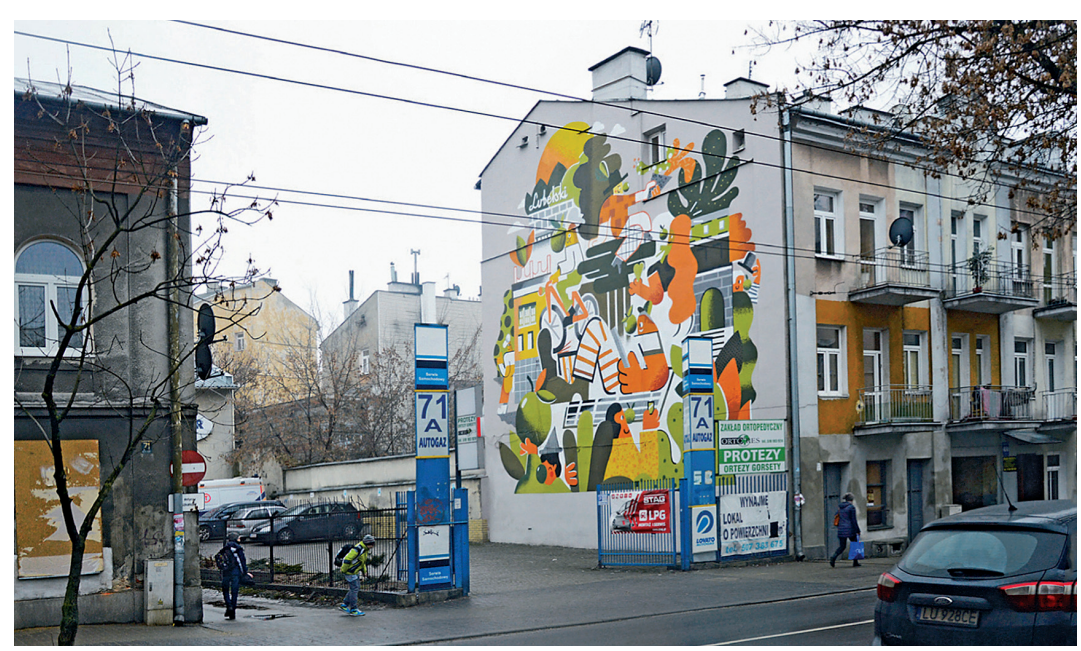

Fig. 10. Mural located on one of the walls of an old building at Lubartowska street in Lublin. Author's photography, $2016 \mathrm{r}$.

Large-format, original wall paintings deliver important, cultural and social messages. Owing to their scale and artistic values, they catch the attention of a great number of street art viewers. That kind of art tends to present taboo subjects and handles some serious social topics. Murals differ from standard commercial types of big-scale advertising in their unique presentation technique, unobvious exposition, scale, artistic measures applied. 
Given examples illustrate how a forgotten, ordinary public space can turn into artistically appealing fragment of the city. Before we say,no' to the street art, it might be beneficial to rethink possible solutions which would have positive effects on public spaces of the city and its citizens.

The majority in the society treat advertising as a necessary element of their social lives. It has become a symbol of a new social order in the times of consumerism and globalisation. Nothing speaks louder about the culture of a given city than the aesthetics of a public space accessible for all. In that sense, a message stops being just a container for meaning; it creates the culture of the city. Advertising reserves recently nobody's space and turns it into a place that is full of meaning and friendly to its users.

Taking into account the presented analysis, it might be observed that advertising, in order to exist, needs its viewers in as much as the city needs the advertising or people need the city.

\section{Conclusion}

Photographic advertising image forms a sort of graphics of a given city. As was explained in the analysis, contemporary processes of information transfer are inextricably linked with the presence of outdoor advertising media in a public space. They perform a commercial role being, at the same time, greatly important way of social interaction. Advertising images cause both positive and negative effects in the city substance. Current demands of the market refer not so much to the quality of a product but to the knowledge of how to promote it using efficient visual means. One of such means would be advertising relying on a strong photographic image which becomes, like no other form of interaction, so entrenched in a consumer's memory. One of the key elements of market dynamics is an interchange with current and prospective consumers. Within this context, advertising is one of the most important source of information which serves as not only a kind of entertainment but also a reservoir of photographic images.

A photographic image aspires to a form of art., offering both aesthetical pleasure and a powerful tool of persuasion. Photography emits a plethora of information on a product values. Textual data have been outnumbered by creative, communicative, visual information.

Photography is an art of image capture and pictures undergo the same processes of artistic creation as regular works of art. Wide range of methods of image processing allows for the modulation of reality and the supletion of additional content present in the forms of drawing or painting.

The perception process follows specific rules of interpreting advertising image. Resorting to that process, a photographer is equipped with a vast range of manipulation techniques influencing the addressee's reaction to an image. Eventually, the final effect of a photographic advertising image is to influence people's perception and conscience [11].

A sustainable, safe and vibrant city needs adequate visual space enabling a direct contact of a local community. Seeing and hearing are the most fundamental activities giving the ground for some other forms of interpersonal relations thanks to which people experience a life in the city, some joyful moments, its beaty.

In conclusion, the analysis have shown that the most efficient form of advertising is the one with a strong, dominant visual content. As a result, people's knowledge is mainly gathered from the content accessible via eyesight. A visual image shapes both positive and negative connotations which influence the viewer's psyche. The dominance of the visual content over any other type of information relies on the fact that it absorbs whole attention of the addressee. Very often, the illustrators of advertising images are at the same time visual 
artists who use reproductions of some famous painters in creating fantastic collages evoking positive associations in the viewer.

Digital image introduces utmost change in the way we perceive identity and the world around us. Human beings devoid of universal truth, happen to find themselves in a totally different world which is a system of mutual connections, not the place of hierarchical system. Eyesight is the most important human sense which makes us perfect viewers of virtual reality.

\section{Literatura}

[1] Ustawa z dnia 27 marca 2003 r. o planowaniu i zagospodarowaniu przestrzennym (Dz. U. z 2015 r. poz. 199 i 443).

[2] Iveson K., Branded cities: outdoor advertising, urban governance, and the outdoor media landscape, Antipode, 44 (1) (2012) 151-174.

[3] Cronin A. M., Advertising and the metabolism of the city: urban spaces, commodity rhythms, Environment and Planning D, Society and Space, 24 (4) (2006) 615-632.

[4] Portella A. A., Reeve A. R., Visual Pollution in Historic City Centers: Theoretical Concepts to Develop Commercial Signage Controls in Different Cultural Contexts, [w:] Books of Abstracts of IAPS - International Association for People-Environment Studies - Environment, Health and Sustainable Development, Alexandria, 2006.

[5] Wilson R. T., Till B. D., Effects of Outdoor Advertising: Does Location Matter?, Psychology \& Marketing, 28 (9) (2011) 909-933.

[6] Nawrocki T., Miasta nasze a w nich... Refleksje o wplywie reklamy zewnętrznej na miejska, Acta Universitatis Lodziensis. Folia Sociologica, 2011.

[7] Gehl J., Miasta dla ludzi, Wydawnictwo RAM, Kraków 2014.

[8] Szczęsna E., Poetyka reklamy, Wydawnictwo Naukowe PWN, Warszawa 2003.

[9] http://pl.wikipedia.org/wiki/Reklama, [01.11.2008].

[10] Janiszewska K., Korsak R., Kwarciak B., Wiedza o reklamie. Od pomystu do efektu., Wydawca Park Edukacja 2009.

[11] Laszczak M., Psychologia przekazu reklamowego, Wydawnictwo Profesjonalnej Szkoły Biznesu, Kraków 2000.

[12] Golka M., Świat reklamy, Agencja Badawczo-Promocyjna „Artia”, Poznań 1994.

[13] Kall J., Reklama, Polskie Wydawnictwo Ekonomiczne, Warszawa 2009.

[14] Zuziak Z. K., Nowe przestrzenie podróży. Przestrzenie publiczne węzłów transportu, [w:] Przestrzeń publiczna miasta postindustrialnego (red. M. Kochanowski ), Wyd. Politechniki Gdańskiej, Gdańsk 2002.

[15] https://pl.wikipedia.org/wiki/Fotografia.

[16] Beniecewicz-Miazga A., Klauziński E., Górka A., O fotografi-historia, nurty, kierunki, mody, podział, Stowarzyszenie Fotografów CK FOTO, Warszawa 2010.

[17] Iliński M., Raczyński J., Fotografia w życiu codziennym, Wydawnictwo Artystyczne i Filmowe, Warszawa 1978.

[18] Teicher G. (red.), Fototechnika, Wydawnictwo Naukowo-Techniczne, Warszawa 1982.

[19] Fedak J., Fotografia cyfrowa od A do Z, Muza S.A., Warszawa 2004.

[20] Kurowicki J., Wartości estetyczne fotografii, Oficyna Wydawnicza_Wrocław 2002.

[21] Busza J., Wobec fotografii, Wydawnictwo COK, Warszawa 1983.

[22] Mikosz J., Formy reklamy zewnętrznej, „Kultura - Media - Teologia”, 3 (2010) 44-58.

[23] Burtenshaw K., Mahon N., Barfoot C., Kreatywna reklama, Warszawa 2007.

[24] Bernstein D., Billboard! Reklama otwartej przestrzeni, Warszaw 2005.

[25] http://www.wojtkowski.waw.pl/teksty/111/reklama-w-przestrzeni-miejskiej [27.05. 2013].

[26] Wallis A.,: Miasto i przestrzeń. PWN, Warszawa 1987.

[27] http://pl.m.wikpedia.org/wiki/mural, 


\title{
Obraz fotograficzny w przekazie reklamowym jako nieodłączny element krajobrazu miasta
}

\author{
Agnieszka Chęć-Małyszek
}

\author{
Katedra Architektury, Urbanistyki i Planowania Przestrzennego, Wydziat Budownictwa \\ i Architektury, Politechnika Lubelska, e-mail: a.chec-malyszek@pollub.pl
}

Streszczenie: Miasta jako skupiska ludzi stały się idealnym miejscem do wplecenia reklamy w ich krajobraz i trudno dziś sobie wyobrazić wielkie metropolie bez reklamowych bilbordów. W kulturze miasta, reklama stała się nieodzownym elementem krajobrazu, który odgrywa znaczącą rolę w życiu społecznym i kulturalnym mieszkańców, tworząc w ten sposób swoistą kulturę. Nieodłącznym elementem reklamy jest fotografia, która wykorzystywana jest we wszelkiego rodzaju kreacjach, tworząc jeden z najważniejszych środków przekazu. Oglądając reklamy coraz częściej zwracamy uwagę nie tylko na to, co nam chcą sprzedać specjaliści od marketing, ale też jak chcą to zrobić oraz jakim kanałem informacyjnym do nas dotrzeć. Obecność reklamy w przestrzeni publicznej jest stałym elementem, który wpływa na rozwój oraz identyfikację danego miasta.

Słowa kluczowe: obraz, fotografia, reklama, fotografia reklamowa, krajobraz miasta. 